\title{
HUBUNGAN KEBERADAAN PEROKOK DENGAN KEJADIAN ISPA PADA BALITA DI PUSKESMAS PACCERAKKANG MAKASSAR
}

\author{
Irmayani \\ STIKES Nani Hasanuddin Makassar \\ Alamat Korespondensi: (ns.irmayani@gmail.com/082196299771)
}

\begin{abstract}
ABSTRAK
ISPA (infeksi saluran pernapasan akut) adalah proses inflamasi yang disebabkan oleh virus, bakteri, atpikal (mikoplasma), atau aspirasi subtansi asing yang melibatkan suatu atau semua bagian saluran pernapasan. Saluran pernapasan atas (jalan napas atas) terdiri dari hidung, faring, dan laring. Saluran pernapasan bawah terdiri dari bronkus, bronkiolus, dan alveoli. Tujuan penelitian ini adalah untuk mengetahui keberadaan perokok dengan kejadian ispa pada balita di Puskesmas Paccerakkang Makassar. Manfaat penelitian ini adalah bagi ilmiah, bagi masyarakat dan bagi peneliti. Jenis penelitian ini adalah penelitian kuantitatif dengan metode non experimental design menggunakan desain penelitian Cross Sectional, Jumlah sampel sebanyak 48 responden yang didapatkan dengan menggunakan teknik Aksidental Sampling yaitu teknik penetapan sampel diambil berdasarkan ketersediaan elemen dan kemudahan untuk mendapatkannya, selanjutnya dilakukan uji statistik Chi Square dengan nilai kemaknaan $\alpha=0.05$. Hasil penelitian menunjukkan ada hubungan keberadaan perokok dengan kejadian ISPA pada balita di Puskesmas Paccerakkang Makassar $(p=$ 0,000 ). Kesimpulan penelitian menunjukkan ada hubungan keberadaan perokok dengan ISPA pada balita di Puskesmas Paccerakkang Makassar.
\end{abstract}

Kata Kunci : ISPA, Keberdaan Perokok, Status Gizi

\section{PENDAHULUAN}

Infeksi pernapasan akut adalah proses inflamasi yang disebabkan oleh virus, bakteri, atpikal (mikoplasma), atau aspirasi subtansi asing yang melibatkan suatu atau semua bagian saluran pernapasan. Saluran pernapasan atas (jalan napas atas) terdiri dari hidung, faring, dan laring. Saluran pernapasan bawah terdiri dari bronkus, bronkiolus, dan alveoli (Marni, 2014).

Penyakit ISPA adalah penyakit terbanyak yang diderita oleh anak-anak dan dewasa baik di Negara berkembang maupun di negara maju. World Health Organization (WHO) memperkirakan insiden ISPA di negara berkembang $0.29 \%$ (151 juta jiwa) dan Negara industri 0,05\%(5 juta jiwa) (Lantong, dkk., 2016).

Menurut Markamah (2012), ISPA menempati urutan pertama penyakit yang diderita oleh bayi dan balita di indonesia. Prevalensi ISPA di indonesia adalah 25,5\% dengan morbiditas pneumonia pada bayi $2,2 \%$ dan balita $3 \%$ sedangkan mortalitas pada bayi $23,8 \%$ dan balita 15,5\% (Marni, 2014).

Period Prevalence di Indonesia menurut riskesdas $2013(25,0 \%)$ tidak jauh berbeda dengan tahun 2007 (25,5\%). Karakteristik penduduk dengan ISPA tertinggi terjadi pada kelompok umur 1-4 tahun (25,8\%) dan terendah pada kelompok umur 15-24 tahun $(10,4 \%)$. Menurut jenis kelamin, tertinggi pada laki laki $(25,1 \%)$ dan terendah pada perempuan $(24,9 \%)$. Menurut tingkat pendidikan, tertingi pada kelompok tidak sekolah $(16,3 \%)$ dan terendah kelompok tamat D1-D3/PT (9,5\%). Menurut kuantil indeks kepemilikan, tertinggi menengah kebawah $(14,7 \%)$ dan terendah menengah keatas (12,1\%) (Riskesdas, 2013)

Period prevalence dan prevalence ISPA berdasarkan hasil Riskesdas tahun 2013 di di Sulawesi selatan hitung dalam kurun waktu 1 bulan terakhir. Lima kabupataen kota dengan ISPA tertinggi adalah Tanah Toraja $(41,1 \%)$, Toraja Utara $(38,2 \%)$, Bantaeng $(38,0 \%)$, Jeneponto $(37,9 \%)$, dan Luwu $(39,1 \%)$ (Riskesdas, 2013)

Menurut data dari Puskesmas Paccerakkang tahun 2018 ISPA menempati urutan pertama dari 10 penyakit terbesar yang terjadi di wilayah Puskesmas Paccerakkang, yaitu: ISPA, Hipertensi, penyakit sistem pencernaan tidak spesifik, dermatitis dan infeksi kulit, penyakit gusi, myalgia, penyakit pulpa dan jaringan periapikal, cedera bagian tubuh tidak spesifik, gangguan telinga dan otitis media, dan diabetes mellitus.

Menurut laporan bulanan kesehatan Puskesmas Paccerakkang dari bulan januari sampai september tahun 2018 tercatat ada 2.287 kasus ISPA sedangkan pada usia balita sebanyak 492 kasus atau sebanyak $21,51 \%$ 
dengan dengan rata kunjungan balita penderita ISPA 2 - 3 responden/hari

Berdasarkan uraian diatas, diketahui bahwa ISPA merupakan salah satu penyakit dengan angka kesakitan dan kematian yang cukup tinggi pada balita sehingga diperlukan perhatian lebih oleh masyarakat dan petugas kesehatan dalam penanganannya, terutama tentang beberapa faktor risiko yang mempengaruhi kejadian ISPA. Hal inilah yang mendasari penulis untuk meneliti hubungan keberadaan perokok dengan kejadian ISPA pada balita di Puskesmas Paccerakkang Makassar.

\section{BAHAN DAN METODE}

\section{Lokasi, Populasi dan Sampel}

Jenis penelitian ini merupakan penelitian kuantitatif dengan metode non experimental design yaitu berupa penelitian korelasional dengan pendekatan cross-sectional, yang menjelaskan hubungan keberadaan perokok dengan kejadian ISPA pada balita. Penelitian ini dilaksanakan di Puskesmas Pacerakkang Makassar dilaksanakan pada tanggal 19 desember 2018 sampai dengan 17 januari 2019. Populasi dalam penelitian ini adalah seluruh pasien balita yang menderita ISPA di Puskesmas Pacerakkang Makassar dengan jumlah sampel sebanyak 48 balita dengan menggunakan metode pengambilan sampel Aksidental sampling.

1. Kriteria inklusi

a. Keluarga yang membawa balitanya untuk melakukan pemeriksaan di Puskesmas Paccerakkang Makassar.

b. Pasien balita yang didiagnosa ISPA di Puskesmas Paccerakkang Makassar

c. Bersedia menjadi responden

2. Kriteria Ekslusi
a. Balita yang tidak mengalami ISPA
b. Pasien yang bukan usia balita.
c. Pasien yang tidak bersedia untuk diteliti

Pengumpulan Data

1. Data primer

Data yang diperoleh dari sumber langsung dengan menggunakan kuesioner dan observasi.

2. Data sekunder

Data didapatkan dari dinas Kesehatan Kota, digunakan sebagai data pelengkap untuk data primer yang berhubungan dengan masalah yang diteliti seperti jumlah keseluruhan pasien ISPA. Data ini diperoleh dari instansi yang terkait yaitu di Puskesmas Paccerakkang Makassar.
Pengolahan Data

a. Tahap mengumpulkan data dilakukan melalui instrument pengumpulan data

b. Editing, memeriksa kejelasan dan kelengkapan pengisisan instrument pengumpulan data

c. Coding, proses identifikasi dan klarifikasi dari setiap pertanyaan yang terdapat dalam instrument pengumpulan data menurut variabel-variabel yang diteliti.

d. Tahap mendeskripsikan data, yaitu tabel frekuensi atau diagram, serta berbagai ukuran tendensi sentral, maupun ukuran disperse. Tujuannya memahami karakteristik data sampel penelitian.

Tahap pengujian hipotesis, yaitu tahap pengujian terhadap proposisi-proposisi yang dibuat apakah proposisi tersebut ditolak atau diterima serta bermakna atau tidak. Atas dasar pengujian hipotesis inilah keputusan dibuat).

Analisis Data

1. Analisis univariat

Menurut Notoadmodjo dalam buku (Donsu, JDT., 2016: 124). Analisa univariat merupakan analisa data yang menganalisis satu variabel.

2. Analisis Bivariat

Analisa bivariat yaitu analisa data yang menganalisis dua variabel. Analisa jenis ini sering digunakan untuk menegtahui hubungan dan pengaruh $\mathrm{x}$ dan $\mathrm{y}$, analisa bivariat juga dapat digunakan untuk mencari perbedaan variabel $\mathrm{x}$ dengan $\mathrm{z}$ (Donsu, JDT., 2016 :124). Rumus statistik yang digunakan untuk menganalisa faktor yang berhubungan dengan kejadian Rheumatoid Arthritis adalah Chi-Square.

\section{HASIL PENELITIAN}

1. Analisis Univariat

Tabel 1 Distribusi karakteristik responden di Puskesmas Pacerakkang Makassar . $(n=48)$.

\begin{tabular}{|c|l|l|}
\hline karakteristik & $\mathrm{n}$ & $\%$ \\
\hline $\begin{array}{c}\text { Jenis kelamin } \\
\text { Laki-laki }\end{array}$ & 3 & 6,3 \\
Perempuan & 45 & 93,8 \\
\hline Umur responden & & \\
20 - 30 tahun & 20 & 41,7 \\
30 - 40 tahun & 19 & 39,5 \\
40 - 50 tahun & 9 & 18,8 \\
\hline Pekerjaanresponden & & \\
IRT & 42 & 87,5 \\
Pegawai & 4 & 8,3 \\
Wiraswasta & 2 & 4,2 \\
\hline
\end{tabular}




\begin{tabular}{|c|l|l|}
\hline $\begin{array}{c}\text { Pendidikan responden } \\
\text { SD }\end{array}$ & 2 & 4,2 \\
SMP & 8 & 16,7 \\
SMA & 29 & 60,4 \\
PT & 9 & 18,8 \\
\hline Identitas balita & \multicolumn{2}{|l|}{} \\
\hline Jenis kelamin & & \\
Laki-laki & 22 & 45,8 \\
Perempuan & 26 & 54,2 \\
\hline
\end{tabular}

Berdasarkan tabel 1 di atas, dapat diketahui bahwa dari 48 responden jenis kelamin tertinggi adalah perempuan sebanyak 45 responden $(93,8 \%)$ dan terendah berjenis kelamin laki-laki sebanyak 3 responden (6,3\%). Umur tertinggi 20-30 tahun sebanyak 20 responden $(41,7 \%)$,) dan terendah pada umur 41-50 tahun sebanyak 9 responden $(18,8 \%)$. Pekerja tertinggi sebagai IRT sebanyak 42 responden $(87,5 \%)$ dan terendah pada wiraswasta sebanyak 2 responden $(4,2 \%)$. Pendidikan tertinggi SMA sebanyak 29 responden $(60,4 \%)$ dan terendah SD sebanyak 2 responden $(4,2 \%)$. jenis kelamin balita tertinggi perempuan sebanyak 26 balita $(54,2 \%)$, dan terendah sebanyak laki-laki sebanyak 22 balita $(45,8 \%)$.

2. Analisis Bivariat

Tabel 2. Hubungan keberadaan perokok dengan kejadian ISPA di Puskesmas Paccerakkang Makassar.

\begin{tabular}{|c|c|c|c|c|c|c|}
\hline \multirow{2}{*}{$\begin{array}{c}\text { Keberadaan } \\
\text { perokok }\end{array}$} & \multicolumn{4}{|l|}{ Kejadian ISPA } & \multirow{2}{*}{ Total } \\
\cline { 2 - 6 } & Ringan & Sedang & \\
\cline { 2 - 6 } & $\mathrm{n}$ & $\%$ & $\mathrm{n}$ & $\%$ & $\mathrm{n}$ & $\%$ \\
\hline Tidak terpapar & 19 & 39,6 & 3 & 6,3 & 22 & 45.8 \\
\hline perpapar & 8 & 16,7 & 18 & 37,5 & 26 & 54,2 \\
\hline Total & 27 & 56,3 & 21 & 43,8 & 48 & 100,0 \\
\hline \multicolumn{5}{|c}{$\rho=0,000$} \\
\hline
\end{tabular}

Berdasarkan tabel 2 diperoleh data bahwa, dari 48 responden tersebut didapatkan hasil bahwa balita dengan keberadaan perokok, tidak terpapar berjumlah 22 balita diantaranya terdapat 19 balita yang menderita ISPA ringan dan 3 balita yang menderita ISPA sedang, sedangkan untuk balita dengan keberadaan perokok, terpapar berjumlah 26 balita yang diantaranya 8 balita yang menderita ISPA ringan dan 18 balita yang menderita ISPA sedang. Dimana nilai $\rho=$ 0,000 . Karena nilai $\rho<\alpha=0,05$ maka hipotesis nol ditolak dan hipotesis alternatif diterima, dengan interpretasi ada hubungan keberadaan perokok dengan kejadian ISPA pada balita di Puskesmas Paccerakkang Makassar.

\section{PEMBAHASAN}

Hubungan keberadaan perokok dengan kejadian ISPA pada balita di Puskesmas Paccerakkang Makassar. Keterpaparan asap rokok, khususnya bagi anak-anak dapat meningkatkan risiko untuk mengalami ISPA dan gangguan paru-paru di masa mendatang. Anak dan anggota keluarga dari perokok lebih mudah dan lebih sering menderita gangguan pernapasan dibanding anak dan anggota keluarga yang bukan perokok(Layuk, 2013).

Dari 48 responden yang menderita ISPA, jumlah balita dengan terpapar keberadaan perokok lebih banyak yaitu 26 balita di bandingkan balita dengan tidak terpapar keberadaan perokok yaitu hanya 22 karena balita dengan terdapat seseresponden perokok atau lebih dalam rumah akan memperbesar resiko anggota keluarga yang menderita sakit, seperti gangguan pernafasan.

Hal ini dapat dilihat bahwa dari 26 balita yang terpapar di antaranya 8 menderita ISPA ringan dan 18 balita menderita ISPA sedang, sedangkan balita yang tidak terpapar berjumlah 22 balita diantaranya 19 menderita ISPA ringan dan 3 balita ISPA sedang. Hal ini menunjukkan bahwa keterpaparan asap rokok, khususnya bagi balita dapat meningkatkan risiko untuk mengalami ISPA, karna balita dan anggota keluarga dari perokok lebih mudah dan rentang sering menderita gangguan pernapasan sebab balita memiliki daya tahan tubuh lemah, dan sistem imunnya masih belum sempurna sehingga bila ada paparan asap rokok, maka balita lebih cepat terganggu sistem pernapasannya seperti ISPA. Kejadian ISPA pada balita ini juga tidak lepas dari pengaruh faktor lain seperti yaitu status gizi, umur, pemberian ASI tidak memadai, keteraturan pemberian vitamin A, imunisasi tidak lengkap, polusi udara, kepadatan tempat tinggal.

Yusari Asih (2014) yang menunjukkan bahwa hasil analisis hubungan antara paparan rokok dengan kejadian ISPA, diperoleh bahwa adar 38 anak yang terpapar rokok terdapat $84,4 \%$ mengalami kejadian ISPA. Sedangkan 16 responden yang tidak terpapar rokok 31,2 \% responden yang mengalami kejadian ISPA. Hasil uji statistik diperoleh nilai $p=0,000$ maka dapat disimpulkan ada hubungan yang signifikan antara paparan rokok dengan kejadian ISPA

Disini peneliti berasumsi bahwa keberadaan perokok berhungan dengan kejadian ISPA. Bahwa keberadaan seresponden perokok atau lebih di dalam rumah dan Semakin lama terpapar asap 
rokok akan memperbesar risiko anggota keluarga menderita gangguan pernapasan. Asap rokok mengandung nikotin yang terhirup melalui saluran pernafasan dan masuk ke tubuh dapat meningkatkan resiko terjadinaya ISPA khususnya pada balita.

\section{KESIMPULAN}

Adanya hubungan antara keberadaan perokok dengan kejadian ISPA pada balita di Puskesmas Paccerakkang Makassar.

\section{SARAN}

Bagi RSUD Labuang Baji Makassar, agar lebih menekankan komunikasi terapeutik yang sesuai dengan prosedur sebagai kegiatan tetap dalam persiapan pre operasi guna upaya pencegahan kecemasan pasien pre operasi sehingga dapat meningkatkan mutu dan kualitas pelayanan bagi

1 Disaran kepada seluruh tenaga pelayanan kesehatan dan petugas kesehatan untuk dimasukkan dalam program pemerintah untuk melakukan promosi kesehatan pada masyarakat khususnya promosi tentang pentingnya memperhatikan efek yang ditimbulkan oleh asap rokok, bahaya rokok bagi perokok aktif maupun pasif. kandungan-kandungan yang terdapat pada rokok yang dapat membahayakan kesehatan salah satunya yang dapat memicu terjadinya kejadian ISPA di Puskesmas Paccerakkang Makassar.

2 Disarankan penelitian ini diharapkan bisa menjadi bahan acuan dalam menambah bidang ilmu pengetahuan, menambah referensi, kepustakaan di dalam institusi pendidikan.Dapat dijadikan sebagai bahan bacaan dan dapat menambah wawasan peneliti selanjutnya mengenai hubungan keberadaan perokok dengan kejadian ispa pada balita.

\section{DAFTAR PUSTAKA}

Asih, Yusari (2014). Hubungan Status Gizi Dan Paparan Rokok Dengan Kejadian Ispa Pada Balita Di Sukaraja Bandar Lampung. Jurnal Kesehatan Metro Sai Wawai. 1(VII): 41-47

Donsu, J.D.T. (2016). Metodologi Penelitian Keperawatan. Yogyakarta: PT. Pustaka Baru.

Hasdianah, H.R., Siyoto,S., dan Perisyowati, Y. 2014. Gizi Pemanfaatan Gizi Dan Obesitas. Nuha Medika: Yogyakarta.

Lantong, J.F., Asfian, P., \& Erawan, P.E.M., (2017). Faktor Yang Berhubungan Dengan Kejadian ISPA Pada Pekerja Penggilingan Di Desa Wononggere Kecematan Polinggona Kabupaten Kolaka Tahun 2016. Jimkesmas. 6(2):1-11.

Layuk, R.R., Noer, N.N., Wahiduddin. (2013). Faktor yang Berhubungan dengan Kejadian Ispa pada Balita di Lembang Batu Sura. Universitas Hasanuddin Makassar

Marni. (2014). Asuhan keperawatan anak dengan gangguan pernapasan. Jakarta: gosyen publishing.

Nopita,W., \& Mawarti, R., (2016). Hubungan Status Gizi Dengan Kejadian ISPA Di Puskesmas Pembantu (PUSTU) Topeyan Tegalrejo Di Kota Yogyakarta. Unisa. Universitas Aisyiyah Yogyakarta

Riset Kesehatan Dasar 2013. Jakarta

Suwarjeni, VW. (2014). Metodologi penelitian keperawatan. Yogyakarta: Gava Media. 